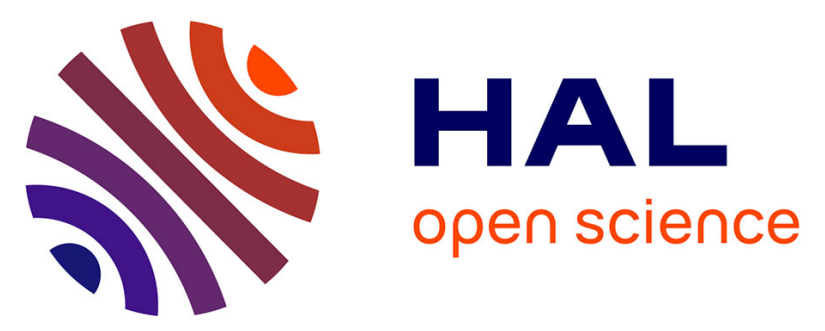

\title{
Don't stay out too long! Thermal tolerance of the stingless bees Melipona subnitida decreases with increasing exposure time to elevated temperatures
}

Camila Maia-Silva, Jaciara da Silva Pereira, Breno M. Freitas, Michael Hrncir

\section{- To cite this version:}

Camila Maia-Silva, Jaciara da Silva Pereira, Breno M. Freitas, Michael Hrncir. Don't stay out too long! Thermal tolerance of the stingless bees Melipona subnitida decreases with increasing exposure time to elevated temperatures. Apidologie, 2021, 52 (1), pp.218-229. 10.1007/s13592-020-00811-z . hal-03372628

\section{HAL Id: hal-03372628 \\ https://hal.science/hal-03372628}

Submitted on 11 Oct 2021

HAL is a multi-disciplinary open access archive for the deposit and dissemination of scientific research documents, whether they are published or not. The documents may come from teaching and research institutions in France or abroad, or from public or private research centers.
L'archive ouverte pluridisciplinaire HAL, est destinée au dépôt et à la diffusion de documents scientifiques de niveau recherche, publiés ou non, émanant des établissements d'enseignement et de recherche français ou étrangers, des laboratoires publics ou privés. 


\title{
Don't stay out too long! Thermal tolerance of the stingless bees Melipona subnitida decreases with increasing exposure time to elevated temperatures
}

\author{
Camila Maia-Silva $^{1,2}$, Jaciara da Silva Pereira ${ }^{1}$, Breno M. Freitas $^{2}$, Michael HrnciR ${ }^{1,3}$ \\ ${ }^{1}$ Departamento de Biociências, Universidade Federal Rural do Semi-Árido, Av. Francisco Mota, nº 572, Presidente \\ Costa e Silva, Mossoró, RN 59625-900, Brazil \\ ${ }^{2}$ Setor de Abelhas, Departamento de Zootecnia, Centro de Ciências Agrárias, Universidade Federal do Ceará, Avenida \\ Mister Hull, s/n Campus do Pici, Fortaleza, CE 60356-000, Brazil \\ ${ }^{3}$ Departamento de Fisiologia, Instituto de Biociências, Universidade de São Paulo, Rua do Matão, travessa 14, n 321 , \\ Cidade Universitária, São Paulo, SP 05508-090, Brazil
}

Received 4 April 2020 - Revised 17 July 2020 - Accepted 22 September 2020

\begin{abstract}
In hot climates, foraging bees risk overheating during food collection. Here, we investigated influence of ambient temperature on the foraging activity in Melipona subnitida, a stingless bee species that naturally occurs in the hottest and driest regions of the Brazilian tropical dry forest. We observed a decrease in round-trip duration of pollen foragers with increasing ambient temperature. Foraging duration of nectar collectors, however, was not affected by the thermal conditions of the environment. When exposed to heat stress in incubators, the upper thermal limits of foragers decreased with increasing exposure time. Moreover, individuals with previous access to liquid food showed higher critical and lethal temperatures than unfed bees. Our study revealed plastic changes in the upper thermal limit of M. subnitida, which help to understand the foraging activity pattern of this stingless bee species.
\end{abstract}

upper thermal limit / critical temperature / lethal temperature / heat stress / foraging activity pattern

\section{INTRODUCTION}

While foraging, bees stay several minutes up to hours in the field (He et al. 2013; Woodgate et al. 2016; Harano et al. 2020). On visiting known resource patches, they spend most of this time collecting food. Translocation between nest and feeding site, by contrast, is swift since it occurs along largely straight flight paths (Reynolds et al. 2007; Woodgate et al. 2016). As long as they are in the field, foragers are exposed to multiple stressors of the outside

Corresponding author: C. Maia-Silva, maiasilvac@gmail.com

Manuscript Editor: James Nieh environment (Klein et al. 2017). Among these, thermal stress has a direct impact on the bees' activity (Willmer 1983; Willmer and Stone 2004). When it is too cold, foragers need to heat up their thorax through muscle shivering to attain the minimum body temperature necessary for flight (Heinrich 1993; Contrera and Nieh 2007). In hot climates, on the other hand, foragers risk overheating. Owing to flight muscle activity, the body temperature of bees, usually, exceeds air temperature by several degrees and even may reach values close to the critical thermal limit of the individuals (Chappell 1982, 1984). Hence, in order to avoid heat death, foragers need to compensate the heat excess through cooling their body (Nicolson and Low 1982; Heinrich and Buchmann 1986; Roberts 
and Harrison 1999) or, alternatively, interrupt food collection (Willmer and Stone 1997, 2004).

Two physiological characteristics, cooling capacity and the upper thermal limit, determine up to which ambient temperature bees may sustain foraging. Cooling occurs mainly through shunting excess heat from the thorax to the abdomen and the head (Heinrich 1980; Heinrich and Buchmann 1986; Souza-Junior et al. 2020) as well as through evaporative and convective heat loss (Nicolson and Louw 1982; Roberts et al. 1998; Roberts and Harrison 1999). Yet, with increasing foraging distance, cooling becomes less efficient, since physiological countermeasures might no longer compensate the extended heat gain associated, primarily, with prolonged flight muscle work (Souza-Junior et al. 2020). Likewise, thermal limits of insects are non-static, species-specific feature. Both critical and lethal temperatures are affected by exposure time (Rezende et al. 2014; Jørgensen et al. 2019), season (Macieira and Proni 2004; Ayton et al. 2016), acclimatization temperature (Kingsolver et al. 2016; Oyen et al. 2016; Gonzalez et al. 2020), and diurnal temperature fluctuations (Colinet et al. 2015). Thus, to understand the activity patterns of bees in hot climates, it is crucial to consider the plasticity of their thermal tolerance.

In the present study, we investigated plastic changes of the heat tolerance associated with exposure time and foraging task in Melipona subnitida Ducke 1910. This stingless bee species (Apidae, Meliponini) naturally occurs in the hottest and driest regions of the tropical dry forest in Northeast Brazil (Giannini et al. 2017). Average air temperatures in this biome are close to $28{ }^{\circ} \mathrm{C}$ throughout the year (Marengo et al. 2017). Daily maxima, however, may easily reach $40{ }^{\circ} \mathrm{C}$ in the shade and even more than $50{ }^{\circ} \mathrm{C}$ in full sunlight (Maia-Silva et al. 2015; Hrncir et al. 2019). As in other bees (Heinrich 1993), the thoracic temperatures of M. subnitida foragers increase with air temperature, exceeding these, on average, by approximately $9.5{ }^{\circ} \mathrm{C}$ (Souza-Junior et al. 2020). Despite more intensive heating of the thorax with increasing flight distance, the bees show similar thoracic temperatures at foraging distances between 15 and $100 \mathrm{~m}$ (Souza-Junior et al. 2020). This thermal stability can be explained through an increasing dissipation of excess heat from the thorax to the head and the abdomen with increasing flight distance (Souza-Junior et al. 2020). Evaporative heat loss at these body parts may compensate the heat gain (Roberts and Harrison 1999). At air temperatures above $30{ }^{\circ} \mathrm{C}$, however, this cooling mechanism is efficient only during short flights. At feeding sites beyond $50 \mathrm{~m}$, the heat gain at the head and abdomen exceeds the cooling capacity, causing an increasing temperature excess in these body parts (Souza-Junior et al. 2020).

The evaporative cooling capacity and, thus, the heat tolerance of bees depend on the access to liquids while foraging (Cooper et al. 1985; Willmer and Stone 1997). Hence, the activity of pollen and nectar foragers should be affected differently by high air temperatures (Cooper et al. 1985; Willmer and Stone 2004). Pollen foragers of $M$. subnitida leave the nest with honey in their crop, which they spent almost entirely to fuel their flight, to pack pollen loads (Harano et al. 2020), and, presumably, for cooling their body. Since they usually do not take up nectar on their foraging trip (Harano et al. 2020), cooling may become insufficient at high ambient temperatures. The consequent elevated heat stress may restrain the activity of pollen foragers, resulting in shorter flights or even the suspension of foraging. Nectar foragers of M. subnitida, by contrast, rarely leave the nest with flight fuel (Harano et al. 2020). However, since they load liquids on their collection trip, cooling at high air temperatures should be more efficient than that of pollen foragers. Thus, the heat tolerance of nectar foragers may be higher than that of pollen foragers (Willmer and Stone 2004; Hrncir et al. 2019). In order to get a better insight into the dynamics of the interaction between ambient temperature and foraging activity in M. subnitida, we asked the following questions: (1) To which extent are foraging trip times of nectar and pollen foragers associated with ambient temperatures? (2) To which extent does heat tolerance change with exposure time to elevated temperatures? (3) To which extent does heat tolerance increase when foragers have access to liquid food? 


\section{MATERIAL AND METHODS}

\subsection{Study site and bees}

The present study was performed between $\mathrm{Au}-$ gust 2015 and August 2016 (experiments on foraging trip duration, see below) and between January and March 2019 (experiments on critical and lethal temperatures, see below) on the campus of the Brazilian Federal University at Mossoró, Brazil (UFERSA). The local climate is hot semi-arid, with annual average air temperatures of $26.5^{\circ} \mathrm{C}$ and mean annual cumulative rainfall of $794 \mathrm{~mm}$ (Alvares et al. 2013). For our experiments, we used six queenright colonies of Melipona subnitida Ducke 1910, a stingless bee species (Apidae, Meliponini) native to the study region (Giannini et al. 2017). The colonies were housed in wooden nest boxes at the university's meliponary (Meliponário Imperatriz) and freely foraged at plants available in the surroundings.

\subsection{Association between air temperature and foraging trip duration}

For investigating the potential association between ambient temperature and foraging trip duration, we recorded the round-trip times of individually marked pollen and nectar foragers of M. subnitida. For marking the bees, we closed the nest entrances between 0600 and $0630 \mathrm{~h}$ and captured all returning foragers individually in plastic vials. Bees were identified as pollen foragers in case they carried a visible pollen load on their corbiculae. As shown in a recent study, pollen foragers of $M$. subnitida are highly specialized and rarely collect nectar on a foraging trip (Harano et al. 2020). Bees without corbicular loads (pollen, clay, or resin), yet returned to the nest with a dilated abdomen, were classified as nectar foragers. Although it is possible that these bees had collected water, the proportion of water foragers usually is low in this bee species (Harano et al. 2020: no workers with crop loads $<10 \%$ sugar concentration, $N=69$ ). In any case, for our rationale, it was important to distinguish between foragers with and without access to any form of liquid (nectar or water) during resource collection. Individuals were briefly anesthetized with $\mathrm{CO}_{2}$
$\left(\mathrm{CO}_{2} \approx 100 \%\right.$ for $\left.10-15 \mathrm{~s}\right)$ and identified with a unique combination of color dots on their thorax (Tinta Plástica, Acrilex®, Brazil). After marking, the bees were released and usually instantly returned to their colonies. On the following 2 days, we recorded the time the individually marked foragers left and returned to their nests during peak foraging activity, between 0500 and $0800 \mathrm{~h}$ (Maia-Silva et al. 2016), and calculated their round-trip times (to the nearest 10 seconds). The six experimental colonies were observed simultaneously by different, trained observers. Ambient air temperature on the bees' return was measured with a digital thermometer (MT-241, Minipa, Brazil) installed in the shade close to the nests. Each individual was assessed only once in order to avoid pseudoreplication. The experiment was repeated monthly between August 2015 and August 2016. In some months (Sep. 15, Nov. 15, Jan. 16, Mar. 16, Apr. 16, May 16, Jun. 16), however, we had no success in recording foraging trip times owing to the reduced collecting activity of the colonies associated, presumably, with a low availability of floral food in the environment (Maia-Silva et al. 2015). In total, we determined the round-trip times of 83 pollen foragers and 55 nectar foragers.

\subsection{Impact of exposure time on upper thermal limits of foragers}

For assessing the potential impact of exposure time to elevated temperatures on the upper thermal limits of M. subnitida foragers, we used constant heat stress assays adapted from the protocol to study lethal temperatures developed by Kovac and co-authors (2014). Between 0600 and $0615 \mathrm{~h}$, we closed the nest entrances and captured all returning pollen foragers with suction tubes. For the assays, we used pollen foragers only since they arrive at the nest with little or even without nectar in their crops (Harano et al. 2020), which allowed a more uniform baseline for the experimental treatments (see below). Bees were briefly anesthetized with $\mathrm{CO}_{2}$ for easier manipulation $\left(\mathrm{CO}_{2} \approx 100 \%\right.$ for $\left.10-15 \mathrm{~s}\right)$ and transferred in groups of between 10 and 15 individuals to cylindric mesh cages (height, $10 \mathrm{~cm}$; diameter, $5 \mathrm{~cm}$ ). Each cage contained foragers of a single colony to 
prevent aggressive and often lethal interactions between bees. Initially, the mesh cages were stored in a Bio-Oxygen Demand incubator (B.O.D. incubator, NT703, Novatecnica, Brazil) at $28{ }^{\circ} \mathrm{C}$ for $1 \mathrm{~h}$. During this acclimation period, half of the experimental groups (feeding treatment $\mathrm{S}+: N=70$ groups, $n=609$ bees) received sugar solution ad libitum (50\% cane sugar weight on weight, offered in a small Petri-dish), whereas the other half (feeding treatment $\mathrm{S}-: N=70, n=583$ ) had no access to liquid food. Since we used only pollen foragers for the experiment, which return to the nest with very little or no flight fuel (Harano et al. 2020), individuals from the feeding treatment $\mathrm{S}-$, presumably, had no liquids left in their crop after the acclimation period. Bees from feeding treatment $\mathrm{S}+$, by contrast, had $1 \mathrm{~h}$ to take up sugar water. Although we did not confirm the consumption of the individuals, the clearly visible reduction of the offered food indicated that at least some bees took up liquid. Immediately after acclimation, the bees were transferred to B.O.D. incubators, preheated to a particular target temperature (between 28 and $55^{\circ} \mathrm{C}$ ). During the trials, the bees received no food. The exact thermal conditions in the incubators were measured with temperature sensors (TMC20-HD, Onset Computer Corporation, USA; accuracy $\pm 0.25^{\circ} \mathrm{C}$ ) positioned next to the mesh cages. Data were stored every $10 \mathrm{~s}$ on a data logger (U12-008, Onset Computer Corporation, USA). Relative humidity was kept at approximately $75 \%$ by placing vials with saturated $\mathrm{NaCl}$-solutions in the incubators (Menezes et al. 2013). The experimental groups remained at the respective target temperature for $6 \mathrm{~min}$ (treatment $\mathrm{A}, N_{\mathrm{S}+}=24$ groups, $n_{\mathrm{S}+}$ $=209$ bees; $N_{\mathrm{S}^{-}}=24, n_{\mathrm{S}^{-}}=194$ ), 20 min (treatment B, $N_{\mathrm{S}_{+}}=24, n_{\mathrm{S}+}=219 ; N_{\mathrm{S}^{-}}=24, n_{\mathrm{S}^{-}}=$ 218 ), or $60 \mathrm{~min}$ (treatment $\mathrm{C}, N_{\mathrm{S}+}=22, n_{\mathrm{S}+}=$ $\left.181 ; N_{\mathrm{S}^{-}}=22, n_{\mathrm{S}^{-}}=171\right)$. Each trial was performed simultaneously with one $\mathrm{S}+$ and one $\mathrm{S}-$ group. The two groups were usually from different colonies and had been assigned to their feeding treatment in a pseudorandom binary sequence prior to the experiment (the first group was assigned at random, and the second group received the alternative treatment). After the experimental period, the bees were transferred to a B.O.D. incubator at $28^{\circ} \mathrm{C}$, where they remained for $8 \mathrm{~h}$, after which we assessed the mortality rate of each group. Individuals were considered dead in case they did not show any movement even after a gentle contact stimulus.

\subsection{Data analysis}

The potential association between ambient temperature and trip duration of pollen and nectar foragers was investigated using Linear Regression Models with air temperature as linear predictor and round-trip time as dependent variable. The coefficient of determination $\left(R^{2}\right.$ adj) explained the goodness of fit of the respective model. Potential differences between pollen and nectar foragers (fixed effect 1, categorical predictor) concerning the association between air temperature (fixed effect 2, linear predictor) and trip duration (response variable) were assessed through a Linear Mixed-Effect Model with study month and colony as random effects (lmer function of Rpackage lme4). The interaction between the categorical predictor (resource collected: pollen or nectar) and the linear predictor (air temperature) indicated whether the slopes of the linear associations between ambient temperature and roundtrip duration differed significantly or not between pollen and nectar foragers.

For assessing the potential impact of exposure time to elevated temperatures on the upper thermal limits of $M$. subnitida foragers, we estimated the upper critical temperatures and the lethal temperatures of the experimental treatments $(\mathrm{AS}+$, $\left.\mathrm{AS}-, \mathrm{BS}+, \mathrm{BS}-, \mathrm{CS}+, \mathrm{CS}^{-}\right)$using ThreeSegment Linear Regression Functions (SigmaPlot for Windows 12.5, Systat Software Inc., USA; user defined function with $y_{\text {max }}=100$ ). The critical temperature (CT) is the thermal threshold above which some sort of physiological failure becomes imminent, causing the reduction of respiratory activity and the impairment of controlled motor activity (Kovac et al. 2014; Ayton et al. 2016). Although animals might recover from this state, they are usually incapable of escaping the thermal stress and will, eventually, die (Mitchell et al. 1993). Thus, since we did not measure metabolic rates or locomotor activity, we defined $\mathrm{CT}$ as the temperature above which we observed a rapid increase in mortality in our experimental 
groups (breakpoint 1, onset of second linear segment). The lethal temperature (LT) was the temperature above which the regression indicated $100 \%$ mortality (breakpoint 2, onset of third linear segment) (Silva et al. 2017). Potential differences between the experimental treatments (fixed effect 1: feeding treatment, categorical predictor; fixed effect 2: exposure time, linear predictor) concerning the association between B.O.D. temperature (fixed effect 3, linear predictor) and mortality (response variable, binomial distribution: dead, alive) were assessed through a Generalized Linear Mixed-Effect Model with colony as random effect (glmer function of R-package lme4). Multiple comparisons between experimental groups were performed using Tukey's Contrast Tests.

Statistical tests were performed in RStudio 1.1.463 (RStudio Inc., U.S.A), R version 3.5.3, at an $\alpha$-level for significant differences of $P \leq$ 0.05 . Throughout the text and in the tables, if not otherwise specified, average values are presented as arithmetical means \pm first standard deviation.
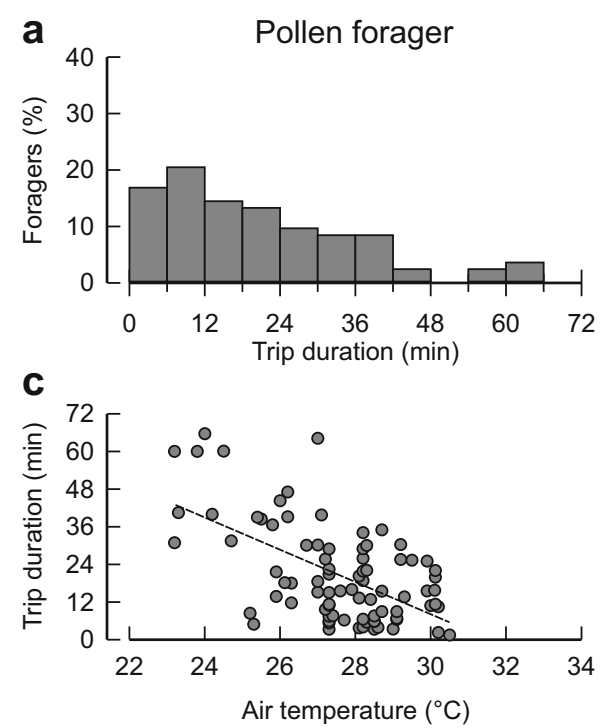

\section{RESULTS}

\subsection{Pollen foragers, but not nectar foragers, reduce foraging trips with increasing air temperature}

During our study, pollen foragers of M. subnitida ( $n=83$ bees) spent on average $20.1 \pm 15.65 \mathrm{~min}$ (minimum $=1.5 \mathrm{~min}$; maximum $=65.7 \mathrm{~min}$ ) in the field. The round-trip times decreased significantly with increasing ambient air temperature (Linear Regression: trip duration $=162.4-5.14 \times$ air temperature, $F_{[1,81]}=41.2, P$ $<0.001$ ) (Figure 1). However, this linear association accounted only for $33 \%$ of the observed variation in pollen foraging times $\left(R^{2}\right.$ adj $=$ $0.329)$. The average round-trip duration of nectar foragers $(n=55)$ was $13.6 \pm 13.34 \mathrm{~min}$ (minimum $=1.8 \mathrm{~min}$; maximum $=60.2 \mathrm{~min})$. Although foraging times tended to decrease with increasing air temperature, this trend was not statistically significant (Linear Regression: trip duration $=55.5-$ $1.40 \times$ air temperature, $F_{[1,53]}=2.0, P=0.164$, $R^{2}$ adj $=0.018$ ) (Figure 1$)$. The slopes of the linear
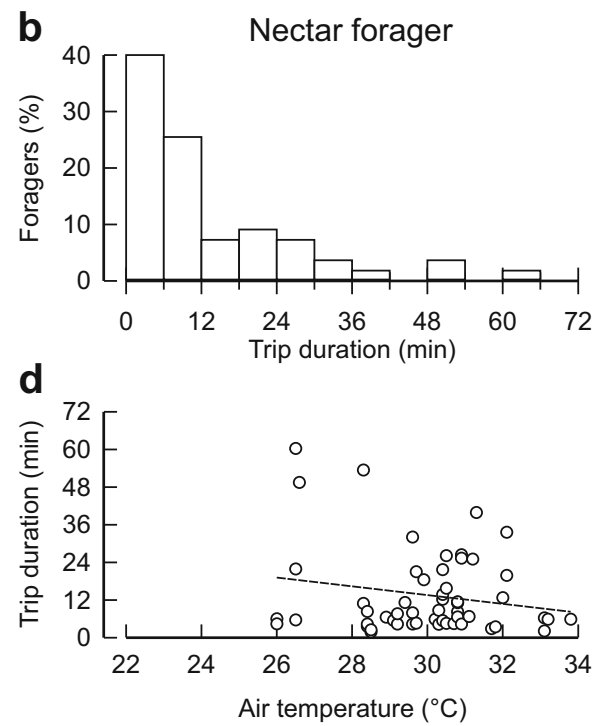

Figure 1. Association between foraging trip duration and air temperature in foragers of Melipona subnitida . Frequency distribution of foraging trip durations in a pollen foragers and $\mathbf{b}$ nectar foragers. Scatterplots showing the association between foraging trip duration and air temperature in $\mathbf{c}$ pollen foragers and $\mathbf{d}$ nectar foragers. Grey bars and circles: pollen foragers $(n=83)$; white bars and circles : nectar foragers $(n=55)$. Dashed lines: linear regression $\left(\mathbf{c}, R^{2}\right.$ adj $=0.329, P<0.001 ; \mathbf{d}, R^{2}$ adj $\left.=0.018, P=0.164\right)$. 
associations between air temperature and roundtrip time differed significantly between pollen foragers and nectar foragers (Linear MixedEffect Model, resource $\times$ air temperature: Wald Chi-Squared Test: $\chi^{2}=10.1, P=0.002$ ).

\subsection{Exposure time and access to liquid food affect upper thermal limits}

Exposure time and feeding treatment significantly affected the upper thermal limits of M. subnitida (Generalized Linear MixedEffect Model: effect exposure time: $\chi^{2}=$ 125.4, $P<0.001$; effect feeding treatment: Wald Chi-Squared Test: $\chi^{2}=39.8, P<$ $0.001)$. Both critical and lethal temperatures of foragers diminished with increasing exposure time to elevated temperatures in B.O.D. incubators (Figure 2; Table I). Moreover, at exposure times of 20 and $60 \mathrm{~min}$, bees showed higher upper thermal limits when they had had access to liquid food prior to heat exposure (Figure 2; Table I). Critical temperatures ranged between $41.6{ }^{\circ} \mathrm{C}$ (exposure time $=60$ min, treatment $\mathrm{S}-$ ) and $52.0{ }^{\circ} \mathrm{C}$ (exposure time $=6 \mathrm{~min}$, treatment $\mathrm{S}+$ ) and lethal temperatures between $42.9{ }^{\circ} \mathrm{C}$ (exposure time $=60 \mathrm{~min}$, treatment $\mathrm{S}-$ ) and $54.8{ }^{\circ} \mathrm{C}$ (exposure time = 6 min, treatment $\mathrm{S}+$ ), respectively (Table I).

\section{DISCUSSION}

The results of our study demonstrate plastic changes in the upper thermal limits of M. subnitida. Both critical and lethal temperatures of the bees were significantly influenced by exposure time to elevated temperatures and previous access to liquid food. Thus, with increasing ambient temperature and concomitant increasing thoracic temperature, foragers should reduce their time in the field or even abandon food collection to avoid heat death. a

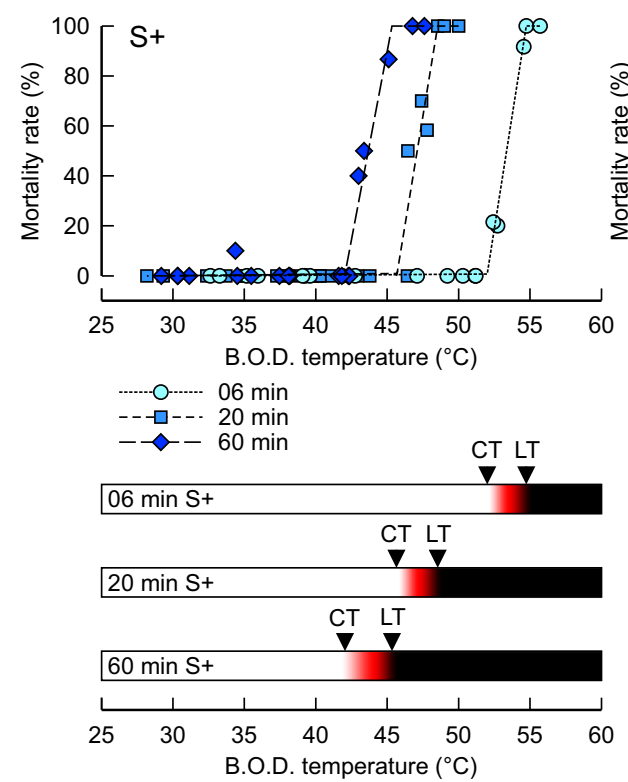

b

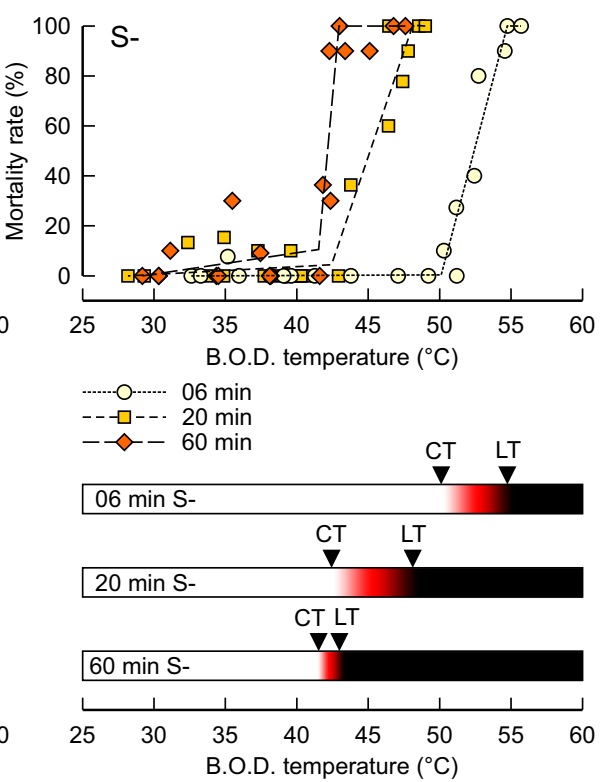

Figure 2. Plasticity of upper thermal limits in foragers of Melipona subnitida. Given are mortality rates of forager groups maintained in mesh cages within B.O.D incubators at the given temperatures for 6 min (circles), 20 min (squares), or $60 \mathrm{~min}$ (diamonds). Each symbol represents one experimental group comprising between 10 and 15 individuals. Prior to heat exposure, experimental groups either received liquid food (a, treatment $\mathrm{S}+$ ) or remained unfed (b, treatment $\mathrm{S}-$ ). Black dashed lines indicate Three-Segment Linear Regressions used to estimate critical temperatures (CT) and lethal temperatures (LT) of the experimental treatments. 
Table I.. Critical and lethal temperatures of foragers of Melipona subnitida after different exposure times to heat stress. Given are average critical temperatures (CT) and lethal temperatures (LT) \pm standard error of the different experimental treatments calculated through Three-Segment Linear Regressions. S+, bees with previous access to liquid food; $\mathrm{S}-$, unfed bees; $N$, number of experimental groups; $n$, number of bees

\begin{tabular}{|c|c|c|c|c|c|c|c|c|}
\hline \multicolumn{4}{|c|}{ Treatment } & \multicolumn{5}{|c|}{ 3-Segment Linear Regression } \\
\hline Time & Food & $\mathrm{CT}$ & $\mathrm{LT}$ & $F$ & $R^{2}$ adj & $N$ & $n$ & Difference $^{1}$ \\
\hline \multirow[t]{2}{*}{$06 \mathrm{~min}$} & $\mathrm{~S}+$ & $52.0 \pm 0.06$ & $54.8 \pm 0.04$ & $2738.7^{* * * *}$ & 0.997 & 24 & 209 & a \\
\hline & $\mathrm{S}-$ & $50.2 \pm 0.36$ & $54.7 \pm 0.27$ & $158.0^{* * * *}$ & 0.943 & 24 & 194 & $\mathrm{a}$ \\
\hline \multirow[t]{2}{*}{$20 \mathrm{~min}$} & $\mathrm{~S}+$ & $45.7 \pm 0.27$ & $48.6 \pm 0.21$ & $298.8^{* * * *}$ & 0.961 & 24 & 219 & $\mathrm{~b}$ \\
\hline & $\mathrm{S}^{-}$ & $42.5 \pm 0.51$ & $48.1 \pm 0.35$ & $274.3^{* * * *}$ & 0.958 & 24 & 218 & $\mathrm{c}$ \\
\hline \multirow[t]{2}{*}{$60 \mathrm{~min}$} & $\mathrm{~S}+$ & $42.1 \pm 0.15$ & $45.3 \pm 0.18$ & $510.3^{* * *}$ & 0.982 & 22 & 181 & $\mathrm{c}$ \\
\hline & S- & $41.6 \pm 0.33$ & $42.9 \pm 0.37$ & $84.4^{* * * *}$ & 0.898 & 22 & 171 & $\mathrm{~d}$ \\
\hline
\end{tabular}

$* * * P<0.001$

${ }^{1}$ Generalized Linear Mixed-Effect Model, pairwise comparison with Tukey's Contrast Test, different letters indicate significant difference between treatments $(P \leq 0.05)$

These findings are an important contribution to the understanding of the foraging dynamics of M. subnitida colonies in the Brazilian tropical dry forest. This stingless bee species is an important pollinator in the hottest and driest regions of north-eastern Brazil (Giannini et al. 2017), specialized on native plants that provide high amounts of food (Maia-Silva et al. 2020), but also efficient in crop pollination (Cruz et al. 2005). Owing to the limited availability of floral food throughout the year, restricted mainly to few weeks of rainy season (Quirino and Machado 2014), social bees must harvest and hoard food quickly and efficiently to maintain their colonies during the extended drought periods (Hrncir et al. 2019). Thus, colonies of $M$. subnitida should maximize their foraging effort during these short periods of elevated food supply. However, even when floral resources are abundant, colonies restrict their collecting activity, particularly of pollen, to the early morning hours (Maia-Silva et al. 2015, 2016; Harano et al. 2020). The fact that other bee species in the Brazilian tropical dry forest continue foraging even during the hottest hours of the day (Barreto et al. 2011; Pick and Schlindwein 2011) indicates that the flight activity of $M$. subnitida is not restrained by resource availability and suggests ambient temperature as limiting factor.

\subsection{Foraging trip times are associated with air temperature in pollen foragers but not in nectar foragers}

In their natural habitat, the thermal foraging window of $M$. subnitida pollen foragers is between 20 and $33{ }^{\circ} \mathrm{C}$, whereas nectar collection can be observed up to air temperatures of $37^{\circ} \mathrm{C}$ (Maia-Silva et al. 2015; Hrncir et al. 2019). This differential activity may be due to differences in cooling capacity between the forager groups. Nectar foragers may use the liquids stored in the crop to increase evaporative cooling either through regurgitating their crop content (shown for Apis mellifera: Cooper et al. 1985) or through elevated tracheal water loss (A. mellifera: Roberts and Harrison 1999; mason bees, Chalicodoma sicula: Willmer 1986). Pollen foragers, however, leaving the nest with few microliters of flight fuel (A. mellifera: Harano and Nakamura 2016; M. subnitida: Harano et al. 2020), would quickly expend their crop content for cooling, risking an increase in hemolymph osmotic concentration and overheating at elevated ambient temperatures (A. mellifera: Roberts and Harrison 1999; 
C. sicula: Willmer 1986; Centris pallida: Roberts et al. 1998). Thus, nectar foragers may tolerate higher air temperatures and withstand heat stress for longer time periods than do pollen foragers. Moreover, owing to elevated cooling efficiency, nectar foragers, presumably, compensate better for variations in ambient temperature (A. mellifera: Cooper et al. 1985; C. sicula: Willmer 1986). These differences in cooling performance between nectar and pollen foragers could explain our finding that nectar collection times were largely independent of ambient temperature, whereas pollen foragers significantly shortened their round-trips with increasing air temperature.

\subsection{Heat tolerance of foragers changes with exposure time and access to liquid}

Despite a sound theoretical and experimental background on heating and cooling capacities of bees (summarized in: Heinrich 1993; Willmer and Stone 2004), little is known about plastic changes in the thermal limits of foragers. So far, studies demonstrated intraspecific differences in thermal performance with season (stingless bees, Scaptotrigona postica : Macieira and Proni 2004; Austroplebeia essingtoni: Ayton et al. 2016) and interspecific differences associated with geographic elevation and, thus, acclimatization temperature (bumble bees, Bombus spp.: Oyen et al. 2016; carpenter bees, Xylocopa spp.: Gonzalez et al. 2020). Our study now provides strong evidence for significant effects of both exposure time to heat stress and access to liquid food on the upper thermal limits of $M$. subnitida foragers. We had opted for a static assay to characterize heat tolerance of the bees, in which individuals were exposed to a constant temperature for a certain time period (Terblanche et al. 2011; Kovac et al. 2014; Rezende et al. 2014; Jørgensen et al. 2019). Since we wanted to determine the potential influence of exposure time on the upper thermal limits of the bees, we could not use dynamic essays, in which animals experience a gradually increasing temperature until cease of controlled motor activity or cyclic respiration (Lighton and Turner 2004; Kovac et al. 2014; Ayton et al. 2016; Jørgensen et al. 2019). Given that the immobilized animals cannot escape the thermal stress, they eventually die (Mitchell et al. 1993). This causes a steep increase in mortality in experimental groups at temperatures above their upper thermal limits, as observed in our study (see also, Silva et al. 2017). Thus, critical thermal maxima established through dynamic assays $\left(\mathrm{dCT}_{\max }\right)$ are compatible with the critical thermal limits estimated from static assays, at least for short exposure times (Kovac et al. 2014: Apis mellifera carnica; dynamic assay: initial temperature $=25{ }^{\circ} \mathrm{C}$, temperature increase $=0.25$ ${ }^{\circ} \mathrm{C} /$ min, activity $\mathrm{dCT}_{\text {max }}=49.2{ }^{\circ} \mathrm{C}$; static assay: initial temperature $=30^{\circ} \mathrm{C}$, temperature increase $=0.4^{\circ} \mathrm{C} / \mathrm{min}, 5 \mathrm{~min}$ at target temperature, $\mathrm{CT}=$ $48.6{ }^{\circ} \mathrm{C}$, calculated from mortality rates after $8 \mathrm{~h}$ presented by the authors).

In our experiments, bees were exposed to an abrupt temperature increase, simulating the natural situation of foragers leaving their nests with an average temperature of $28{ }^{\circ} \mathrm{C}$ (Silva et al. 2017) and entering, instantly, a different thermal environment. Since under experimental confinement, bees are only weakly endothermic (shown for A. mellifera: Kovac et al. 2007, 2014), and the B.O.D. temperatures in our trials, presumably, corresponded largely to bee body temperatures. Cooling at high temperatures, however, certainly occurred, given that groups with access to sugar water prior to the heat stress trials showed higher critical and lethal temperatures than unfed groups at exposure times of 20 and $60 \mathrm{~min}$. Interestingly, the upper thermal limits did not differ significantly between experimental treatments when exposed to heat stress for 6 min only. Presumably, body water reserves of bees without access to liquid food were sufficient to sustain efficient cooling over this short period of time.

Our results suggest that $M$. subnitida tolerates body temperatures up to $52{ }^{\circ} \mathrm{C}$ (with access to liquids) or $50{ }^{\circ} \mathrm{C}$ (without liquid) at exposure times shorter than $6 \mathrm{~min}$. Owing to flight muscle work, active foragers would achieve these thoracic temperatures at air temperatures above $42.5^{\circ} \mathrm{C}$, or $40.5^{\circ} \mathrm{C}$, respectively (average thoracic temperature excess in M. subnitida $\approx 9.5^{\circ} \mathrm{C}$, calculated from the average thoracic excess temperatures of bees foraging at $15 \mathrm{~m}, 50 \mathrm{~m}$, and $100 \mathrm{~m}$; SouzaJunior et al. 2020). Yet, despite the hot climate in 
the bee species' natural habitat, air temperatures above $40{ }^{\circ} \mathrm{C}$ are uncommon and hardly occur during the foragers' activity period (Maia-Silva et al. 2015; Souza-Junior et al. 2020). However, the situation changes dramatically at round-trip times of $20 \mathrm{~min}$. In this case, critical body temperatures of $45.7^{\circ} \mathrm{C}$ (bees with access to liquids) and $42.5{ }^{\circ} \mathrm{C}$ (bees without access to liquids) would be reached at air temperatures of $36.2{ }^{\circ} \mathrm{C}$, and $33{ }^{\circ} \mathrm{C}$, respectively, thermal conditions under which foragers of $M$. subnitida occasionally are active (Hrncir et al. 2019; Souza-Junior et al. 2020).

\subsection{Implications for the foraging of M. subnitida}

The results of our experiments suggest that M. subnitida should avoid long foraging trips at high air temperatures to prevent death through overheating. In experiments with artificial nectar sources containing $60 \%$ sugar solution, foragers of this meliponine species could be lured to distances up to approximately $1 \mathrm{~km}$ (Silva et al. 2014). Considering an average flight velocity of $4 \mathrm{~m} / \mathrm{s}$ (Souza-Junior et al. 2020) and imbibing times of $30 \mathrm{~s}$ (M. seminigra collecting $60 \%$ sugar solutions at artificial nectar feeders; Hrncir et al. 2004), the bees would spend approximately $9 \mathrm{~min}$ for a round-trip at this foraging distance. At natural food sources, however, food uptake may take more than $10 \mathrm{~min}$ (Melipona spp. collecting at Hybanthus prunifolius; Roubik and Buchmann 1984), which increases the foraging duration considerably (for feeding sites at $1 \mathrm{~km}$, the bees would spend approximately $20 \mathrm{~min}$ instead of 9 $\min )$.

In our study, the round-trip times of both nectar and pollen foragers of $M$. subnitida ranged from less than $1 \mathrm{~min}$ to approximately $1 \mathrm{~h}$. Most individuals, however, returned from their collection trips after less than $20 \mathrm{~min}$ (nectar foragers, 76.4 $\%$; pollen foragers, $56.6 \%$ ). Round-trips longer than 20 min occurred at air temperatures below 32 ${ }^{\circ} \mathrm{C}$ in nectar foragers and below $30{ }^{\circ} \mathrm{C}$ in pollen foragers. Estimated thoracic temperatures of 41.5 ${ }^{\circ} \mathrm{C}$ and $39.5{ }^{\circ} \mathrm{C}$, respectively, at these air temperatures (based on average thoracic temperature excess of $\approx 9.5{ }^{\circ} \mathrm{C}$; Souza-Junior et al. 2020) are close to the lowest critical limits established in our experiments (exposure time, $1 \mathrm{~h}$; treatment $\mathrm{S}+$, $\mathrm{TC}=42.1^{\circ} \mathrm{C}$; treatment $\mathrm{S}-, \mathrm{CT}=41.6{ }^{\circ} \mathrm{C}$ ). Thus, natural foraging distances of $1 \mathrm{~km}$, or even more, are thermally feasible for $M$. subnitida, but only if air temperatures remain below 30 to $32{ }^{\circ} \mathrm{C}$. An aggravating factor in this context is the reduced cooling efficiency of $M$. subnitida at air temperatures above $30{ }^{\circ} \mathrm{C}$, which leads to overheating of the head and the abdomen when foraging at resources beyond $50 \mathrm{~m}$ from the nest (Souza-Junior et al. 2020). Thus, the bees must tune both their round-trip times and foraging distances to the respective thermal condition to avoid heat death.

\section{ACKNOWLEDGEMENTS}

We would like to thank Antônio Gustavo MedeirosSilva and Geovan Figueirêdo de Sá Filho for their assistance with the flight time experiments as well as two anonymous referees for their valuable comments. The present study complies with the current Brazilian laws and was financially supported by scholarships of the National Council for Scientific and Technological Development (CNPq: 156147/2018-1) to CMS and of the Brazilian Ministry of Education (CAPES) to JSP and by grants of the of the Brazilian Ministry of Education (CAPES: 3168/2013) and the National Council for Scientific and Technological Development (CNPq: $481256 / 2010-5,404156 / 2013-4 ; 311590 / 2019-5)$ to MH and (CNPq: $302934 / 2010-3,473454 / 2011-4)$ to BMF.

\section{AUTHOR CONTRIBUTION}

Study design and execution of experiments: CMS, JSP, and MH. Data analysis: CMS and MH. Manuscript preparation: CMS, BMF, and MH. Project supervision: $\mathrm{BMF}$ and $\mathrm{MH}$.

\section{COMPLIANCE WITH ETHICAL STANDARDS}

Conflict of interest The authors declare that they have no conflict of interest.

Ne restez pas trop longtemps dehors ! La tolérance thermique des abeilles sans dard Melipona subnitida diminue avec l'augmentation du temps d'exposition à des températures élevées 
limite thermique supérieure / température critique / température létale / stress thermique / butinage

\section{Bleib nicht zu lange draußen! Die thermische Toleranz der stachellosen Biene Melipona subnitida sinkt mit zunehmender Exposition gegenüber erhöhter Temperatur}

oberes Temperaturlimit / kritische Temperatur / letale Temperatur / Hitzestress / Sammelaktivität

\section{REFERENCES}

Alvares C.A., Stape J.L., Sentelhas P.C., Gonçalves J.L.M. (2013) Modeling monthly mean air temperature for Brazil. Theor. Appl. Climatol. 113, 407-427, https://doi.org/10.1007/s00704-012-0796-6

Ayton S., Tomlinson S., Phillips R.D., Dixon K.W., Withers P.C. (2016) Phenophysiological variation of a bee that regulates hive humidity, but not hive temperature. J. Exp. Biol. 219, 1552-1562, https://doi.org/10.1242 /jeb. 137588

Barreto A.Q., Carvalho C.A.L., Lêdo C.A.S., Sodré G.S. (2011) Phenology of bees (Hymenoptera: Apoidea) in a fragment of seasonal semidecidual forest in Bahia, Brazil. Sociobiology 58, 393-402

Chappell M.A. (1982) Temperature regulation of carpenter bees (Xylocopa californica) foraging in the Colorado desert of southern California. Physiol. Zool. 55, 267280, https://doi.org/10.1086/physzool.55.3.30157890

Chappell M.A. (1984) Temperature regulation and energetics of the solitary bee Centris pallida during foraging and intermale mate competition. Physiol. Zool. 57, 215-225, https://doi.org/10.1086 /physzool.57.2.30163707

Colinet H., Sinclair B.J., Vernon P., Renault D. (2015) Insects in fluctuating thermal environments. Annu. Rev. Entomol. 60, 123-140, https://doi.org/10.1146 /annurev-ento-010814-021017

Contrera F.A.L., Nieh J.C. (2007) The effect of ambient temperature on forager sound production and thoracic temperature in the stingless bee, Melipona panamica . Behav. Ecol. Sociobiol. 61, 887-897. https://doi. org/10.1007/s00265-006-0317-7

Cooper P.D., Schaffer W.M., Buchmann S.L. (1985) Temperature regulation of honey bees (Apis mellifera) foraging in the Sonoran desert. J. Exp. Biol. $114: 1-15$

Cruz D.O., Freitas B.M. Silva L.A. Silva E.M.S. Bomfim I.G.A. (2005) Pollination efficiency of the stingless bee Melipona subnitida on greenhouse sweet pepper. Pesq. Agropec. Bras. 40, 1197-1201, https://doi. org/10.1590/S0100-204X2005001200006
Giannini T.C., Maia-Silva C., Acosta A.L., Jaffé R., Carvalho A.T., Martins C.F., Zanella F.C.V., Carvalho C.A.L., Hrncir M., Saraiva A.M., Siqueira J.O., Imperatriz-Fonseca V.L. (2017) Protecting a managed bee pollinator against climate change: strategies for an area with extreme climatic conditions and socioeconomic vulnerability. Apidologie 48, 784-794, https://doi.org/10.1007/s13592-017-0523-5

Gonzalez V.H., Hranitz J.M., Percival C.R., Pulley K.L., Tapsak S.T., Tscheulin T., Petanidou T., Barthell J.F. (2020) Thermal tolerance varies with dim-light foraging and elevation in large carpenter bees (Hymenoptera: Apidae: Xylocopini). Ecol. Entomol., https://doi. org/10.1111/een.12842

Harano K., Nakamura J. (2016) Nectar loads as fuel for collecting nectar and pollen in honeybees: adjustment by sugar concentration. J. Comp. Physiol. A 202, 435443. https://doi.org/10.1007/s00359-016-1088-X

Harano K., Maia-Silva C., Hrncir M. (2020) Adjustment of fuel loads in stingless bees (Melipona subnitida). J. Comp. Physiol. A 206, 85-94, https://doi.org/10.1007 /s00359-019-01398-2

He X., Wang W., Qin Q., Zeng Z., Zhang S., Barron A.B. (2013) Assessment of flight activity and homing ability in Asian and European honey bee species, Apis cerana and Apis mellifera, measured with radio frequency tags. Apidologie 44, 38-51, https://doi.org/10.1007 /s13592-012-0156-7

Heinrich B. (1980) Mechanisms of body-temperature regulation in honeybees, Apis mellifera II. Regulation of thoracic temperature at high air temperatures. J. Exp. Biol. 85, 73-87

Heinrich B. (1993) The hot-blooded insects - strategies and mechanisms of thermoregulation. Springer Verlag, Berlin. https://doi.org/10.1007/978-3-662-10340-1

Heinrich B., Buchmann S.L. (1986) Thermoregulatory physiology of the carpenter bee, Xylocopa varipuncta . J. Comp. Physiol. B 156, 557-562, https://doi. org/10.1007/BF00691042

Hrncir M., Jarau S., Zucchi R., Barth F.G. (2004) Thorax vibrations of a stingless bee (Melipona seminigra). II. Dependence on sugar concentration. J. Comp. Physiol. A 190, 549-560. https://doi.org/10.1007/s00359-0040515-6

Hrncir M., Maia-Silva C., Teixeira-Souza V.H.S., Imperatriz-Fonseca V.L. (2019) Stingless bees and their adaptations to extreme environments. J. Comp. Physiol. A 205, 415-426, https://doi.org/10.1007 /s00359-019-01327-3

Jørgensen L.B., Malte H., Overgaard J. (2019) How to assess Drosophila heat tolerance: Unifying static and dynamic tolerance assays to predict heat distribution limits. Funct. Ecol. 33, 629-642, https://doi. org/10.1111/1365-2435.13279

Kingsolver J.G., MacLean H., Goddin S.B., Augustine K.E. (2016) Plasticity of upper thermal limits to acute and chronic temperature variation in Manduca sexta larvae. J. Exp. Biol. 219, 1290-1294, https://doi. org/10.1242/jeb.138321 
Klein S., Cabirol A., Devaud J.M., Barron A.B., Lihoreau M. (2017) Why bees are so vulnerable to environmental stressors. Trends Ecol. Evol. 32 , 268-278, https://doi.org/10.1016/j.tree.2016.12.009

Kovac H., Stabentheiner A., Hetz S.K., Petz M., Crailsheim K. (2007) Respiration of resting honeybees. J. Insect Physiol. 53, 1250v1261, https://doi.org/10.1016/j. jinsphys.2007.06.019

Kovac H., Käfer H., Stabentheiner A., Costa C. (2014) Metabolism and upper thermal limits of Apis mellifera carnica and A. m. ligustica. Apidologie 45, 664-677, https://doi.org/10.1007/s13592-014-0284-3

Lighton J.R.B., Turner R.J. (2004) Thermolimit respirometry: an objective assessment of critical thermal maxima in two sympatric desert harvester ants, Pogonomyrmex rugosus and P. californicus. J. Exp. Biol. 207, 1903-1913, https://doi.org/10.1242 /jeb.00970

Macieira O.J.D., Proni E.A. (2004) Capacidade de resistência a altas e baixas temperaturas em operárias de Scaptotrigona postica (Latreille) (Hymenoptera, Apidae) durante os períodos de verão e inverno. Rev. Bras. Zool. 21, 893-896, https://doi.org/10.1590 /S0101-81752004000400025

Maia-Silva C., Hrncir M., Silva C.I., Imperatriz-Fonseca V.L. (2015) Survival strategies of stingless bees (Melipona subnitida) in an unpredictable environment, the Brazilian tropical dry forest. Apidologie 46, 631-643, https://doi.org/10.1007/s13592-0150354-1

Maia-Silva C., Hrncir M., Imperatriz-Fonseca V.L., Schorkopf D.L.P. (2016) Stingless bees (Melipona subnitida) adjust brood production rather than foraging activity in response to changes in pollen stores. J. Comp. Physiol. A 202, 723-732, https://doi. org/10.1007/s00359-016-1095-y

Maia-Silva C., Limão A.A.C., Silva C.I., ImperatrizFonseca V.L., Hrncir M. (2020) Stingless bees (Melipona subnitida) overcome severe drought events in the Brazilian tropical dry forest by opting for highprofit food sources. Neotrop. Entomol., https://doi. org/10.1007/s13744-019-00756-8

Marengo J.A., Torres R.R., Alves L.M. (2017) Drought in Northeast Brazil - past, present, and future. Theor. Appl. Climatol. 129, 1189-1200, https://doi. org/10.1007/s00704-016-1840-8

Menezes C., Vollet-Neto A., Imperatriz-Fonseca V.L. (2013) An advance in the in vitro rearing of stingless bee queens. Apidologie 44, 491-500, https://doi. org/10.1007/s13592-013-0197-6

Mitchell J.D., Hewitt P.H., van der Linde T.C., De K. (1993) Critical thermal limits and temperature tolerance in the harvester termite Hodotermes mossambicus (Hagen). J. Insect Physiol. 39, 523528. https://doi.org/10.1016/0022-1910(93)90085-6

Nicolson W.W., Louw G.N. (1982) Simultaneous measurement of evaporative water loss, oxygen consumption, and thoracic temperature during flight in a carpenter bee. J. Exp. Zool. 222, 287-296, https://doi. org/10.1002/jez.1402220311
Oyen K.J., Giri S., Dillon M.E. (2016) Altitudinal variation in bumble bee (Bombus) critical thermal limits. J. Therm. Biol. 59, 52-57, https://doi.org/10.1016/j. jtherbio.2016.04.015

Pick R.A., Schlindwein C. (2011) Pollen partitioning of three species of Convolvulaceae among oligolectic bees in the Caatinga of Brazil. Plant Syst. Evol. 293, 147-159. https://doi.org/10.1007/s00606-011-0432-4.

Quirino Z., Machado I. (2014) Pollination syndromes in a Caatinga plant community in northeastern Brazil: seasonal availability of floral resources in different plant growth habits. Braz. J. Biol. $74: 62-71$, https://doi. org/10.1590/1519-6984.17212

Reynolds A.M., Smith A.D., Reynolds D.R., Carreck N.L., Osborne J.L. (2007) Honeybees perform optimal scalefree searching flights when attempting to locate a food source. J. Exp. Biol. 210, 3763-3770, https://doi. org/10.1242/jeb.009563

Rezende E.L., Castañeda L.E., Santos M. (2014) Tolerance landscapes in thermal ecology. Funct. Ecol. 28, 799809. https://doi.org/10.1111/1365-2435.12268

Roberts S.P., Harrison J.F. (1999) Mechanisms of thermal stability during flight in the honeybee Apis mellifera. J. Exp. Biol. 202, 1523-1533

Roberts S.P., Harrison J.F., Hadley N.F. (1998) Mechanisms of thermal balance in flying Centris pallida (Hymenoptera: Anthophoridae). J. Exp. Biol. 201, 2321-2331

Roubik D.W., Buchmann S.L. (1984) Nectar selection by Melipona and Apis mellifera (Hymenoptera: Apidae) and the ecology of nectar intake by bee colonies in a tropical forest. Oecologia 61, 1-10. https://doi. org/10.1007/BF00379082

Silva A.G., Pinto R.S., Contrera F.A.L., Albuquerque P.M.C., Rêgo, M.M.C. (2014) Foraging distance of Melipona subnitida Ducke (Hymenoptera: Apidae). Sociobiology 61, 494-501. https://doi.org/10.13102 /sociobiology.v61i4.494-501

Silva M.A., Ferreira N.S., Teixeira-Souza V.H.S., MaiaSilva C., Oliveira F.A., Hrncir M. (2017) On the thermal limits for the use of stingless bees as pollinators in commercial greenhouses. J. Apicult. Res. 56, 81-91, https://doi.org/10.1080/00218839.2016.1260380

Souza-Junior J.B.F., Teixeira-Souza V.H.S., OliveiraSouza A., Oliveira P.F., Queiroz J.P.A.F., Hrncir M. (2020) Thermal stress constrains foraging distance of stingless bees (Melipona subnitida) in the Brazilian tropical dry forest. J. Insect Physiol. under revision

Terblanche J.S., Hoffmann A.A., Mitchell K.A., Rako L., le Roux P.C., Chown S.L. (2011) Ecologically relevant measures of tolerance to potentially lethal temperatures. J. Exp. Biol. 214, 3713-3725, https://doi. org/10.1242/jeb.061283

Willmer P.G. (1983) Thermal constraints on activity patterns in nectar-feeding insects. Ecol. Entomol. 8, 455469, https://doi.org/10.1111/j.1365-2311.1983. tb00524.x

Willmer P.G. (1986) Foraging patterns and water balance: problems of optimization for a xerophilic bee, 
Chalicodoma sicula. J. Anim. Ecol. 55, 941-962. https://doi.org/10.2307/4426

Willmer P.G., Stone G.N. (1997) Temperature and water relations in desert bees. J. Therm. Biol. 22, 453-465, https://doi.org/10.1016/S0306-4565(97)00064-8

Willmer P.G., Stone G.N. (2004) Behavioral, ecological, and physiological determinants of the activity patterns of bees. Adv. Study Behav. 34, 347-466, https://doi. org/10.1016/S0065-3454(04)34009-X
Woodgate J.L., Makinson J.C., Lim K.S., Reynolds A.M., Chittka L. (2016) Life-long radar tracking of bumblebees. P.L.o.S. ONE 11, e 0160333, https://doi. org/10.1371/journal.pone. 0160333

Publisher's note Springer Nature remains neutral with regard to jurisdictional claims in published maps and institutional affiliations. 